\title{
OBSERVATIONAL ANALYSIS ON RESULT OF YSZ COATED PISTON CROWN ON THE BEHAVIOUR OF A PETROL ENGINE
}

\author{
Muhammad Asad Riaz \\ Mechanical Engineer, Bahauddin Zakariya University, Multan, Punjab, Pakistan. \\ (Engineering Student, Department of Mechanical Engineering, Bahauddin Zakariya University, Multan, Punjab, Pakistan)
}

Article DOI: https://doi.org/10.36713/epra8270

DOI No: 10.36713/epra8270

\begin{abstract}
An observational study of thermal barrier coating (TBC) on the working of 4-stroke single cylinder petrol engine was studied. Yttria Stabilized Zirconia (YSZ) used as coating material. YSZ has less thermal conductivity, sustainability under high temperature and pressure. Main aim of TBC is to decrease heat losses to the cooling jacket of the engine. YSZ is coated on the piston crown by Plasma spray method. YSZ coating improves the performance of petrol engine. Experimental study was carried out on 4-stroke single cylinder $\mathrm{OHV}$ petrol engine $25^{\circ} \mathrm{C}$ inclined cylinder horizontal shaft engine on performance of ceramic coated engine and compared with baseline engine under different speed. Results show that ceramic coated engine is more effective than conventional engine as brake specific fuel consumption (BSFC) is reduced 2-4\% than normal piston engine, brake thermal efficiency (BTE) of modified engine is expanded 4-8\% than unmodified engine. Indicated thermal efficiency (ITE) of modified piston engine is increased 5-10\% than normal engine. Mechanical efficiency (ME) of the TBC engine is increased 4-10\% than standard engine. Volumetric efficiency (VE) of modified engine is decreased 3-9\% when compared with standard engine and exhaust gas temperature (EGT) of ceramic coated engine is increased 1-3\% than unmodified engine.

KEYWORDS: Petrol Engine, Thermal barrier coating (TBC), Yttria Stabilized Zirconia (YSZ). Mechanical Efficiency
\end{abstract}

\section{INTRODUCTION AND BACKGROUND}

In practice it is impossible to have a $100 \%$ adiabatic engine. At best the engine can reach $50-60 \%$ of adiabatic with advanced ceramics. In many cases the adiabatic engine is called the low heat rejection engine (LHRE), which more accurately describes the technology available today. As described earlier in an adiabatic engine there is no heat added or rejected. Theoretically one would like to make use of the exhaust that is released by the engine. The use of a turbocharger idealizes the no heat rejected concept by taking the high temperature exhaust and transferring work to the engine. In petrol engine EGT changes between $400-600^{\circ} \mathrm{C}$ for standard engine but in case of thermal barrier coated engine it changes between $700-900^{\circ} \mathrm{C}$, while in turbo-charged engine it reached up to $1100^{\circ} \mathrm{C}$. when temperature in thermal barrier coated engine reached such high temperature than the exhaust gasses such as carbon monoxide, Nitrogen oxide and many other hydrocarbons oxidize and exhaust gasses become less pollutant when compared with normal exhaust gasses. In figure 1.1 energy balance for conventional engine and ceramic coated engine is compared Büyükkaya. Ceramic material is light in weight and durable under high temperature and pressure which results improvement in results shows. Bryzik and Kamo reported that $35 \%$ reduction in engine dimensions and reduction in fuel consumption is $17 \%$ in $\mathrm{TBC}$ engine design in military tanks. In modern era, continues decrease in fossil fuels and increase in automobiles is directed towards invention to use fuels economically and increase 


\section{SJIF Impact Factor 2021: 8.013| ISI I.F.Value:1.241| Journal DOI: 10.36713/epra2016 $\quad$ ISSN: 2455-7838(Online) EPRA International Journal of Research and Development (IJRD)}

Volume: 6 | Issue: 8 | August 2021

- Peer Reviewed Journal

the performance of the engine. So, the engine always actuality undertakes on research, S. Jaichandar and P. Tamilporai [1]

Observational setup was conducted on ceramic material coating on the diesel engine performance of coating with $0.5 \mathrm{~mm}, 1 \mathrm{~mm}$ and baseline engine. Results shows that brake thermal efficiency (BTE) for $1 \mathrm{~mm}$ ceramic coating is decreased $6 \%$ as the speed is increased but BTE for $0.5 \mathrm{~mm}$ coating is increased up to $10 \%$ when compare with conventional engine. Exhaust gas temperature of $1 \mathrm{~mm}$ ceramic coated engine is increased $10^{\circ} \mathrm{C}$ when compare with $0.5 \mathrm{~mm}$ coated engine and baseline engine. VE decreases as the ceramic coating is increased Dennis Assanis et al [2]. Thermal barrier coated engine reduces the heat losses which increases the indicated thermal efficiency (ITE). In experimental setup, piston head was coated with Titanium dioxide on the diesel engine piston by atmospheric plasma spray method. In experimental setup, engine maintained at $1500 \mathrm{rev} / \mathrm{mint}$ for both modified and uncoated engine. Performance was examined at variable loads of 2,4,6 and $10 \mathrm{~kg}$ and constant speed of $1500 \mathrm{rev} / \mathrm{mint}$. Brake specific fuel consumption (BSFC) decreased more in modified engine when compared with conventional engine. Coated engine increases brake thermal efficiency up to $3 \%$ than the standard engine. ITE is increased up to $3 \%$ from uncoated engine. Mechanical efficiency (ME) of the coated piston is increased up to $2 \%$ when compare with baseline engine Suresh Kumar Rupangudi et al [3]. Experiment was carried out with different load, velocity and injection timing for both coated and baseline engine. In experiment, it can conclude that piston head coating is more efficient than the cylinder crown coating in developing TE, brake power (BP), indicated power (IP) and decrease in the VE. Temperature of exhaust gas of thinly coated piston crown engine has high temperature than the cylinder head coating when compare with conventional engine coating of exhaust gas temperature. Peak cylinder pressure of the conventional engine is more than the cylinder head of coated engine and piston crown coated engine respectively. SFC of the piston head coated engine has less fuel consumption than the baseline engine E. M. Afify, D. E. Kleft [4]. Observational results are that $\mathrm{ZrO}_{2}-\mathrm{Al}_{2} \mathrm{O}_{3}$ coated piston BTE is increased when analyze with $\mathrm{SiC}$ modified piston and uncoated piston engine [5]. Observational examination on effect of TBC of spark ignition petrol engine was studied. Piston, liner, head, ports and valves were used in TBC engine Dennis N. Assanis and Tarun Mathur [6]. An analysis on working and exhaust emission of TBC engine with YSZ coating in combustion chamber was studied and compare with baseline engine. Results shows that it BSFC is decreased, TE is increased, in experiment various condition were studies that are fuel flow, exhaust temperature, exhaust emissions and fuel flow. Results indicates that improvements in performance and emission [7]. BTE is increased 3\% when compare with uncoated engine. ME is increased $2 \%$ more than conventional engine. Air-fuel ratio for modified engine is comparably more than conventional engine. Substantial expansion in exhaust gas temperature of coated engine compare to uncoated engine Suresh Kumar Rupangudi et al [8]. TBC is providing insulation which decrease heat losses. TBC engine working and emission results were comparing with conventional engine. BSFC of coated engine is decreased $\mathrm{kg} / \mathrm{KWh}$, BTE of coated engine is increased $5.99 \%$ when compare with conventional engine. HC emissions was decreased when compare with baseline engine Jayaram MUTHUSAMY et al [9]. In combustion engine the biggest quantity of energy transfers to environment in the form of thermal waste. A thin coating of ceramics material to the aluminum alloy piston reduced the thermal waste of energy which used as useful work. TBC of ceramics decrease the mass of fuel consumption $4.12 \%$, BTE increases $12 \%$, SFC decreases $2.65 \%$ and emissions reduced. [10].

In this paper work is carried out on 4-stroke single cylinder overhead valve (OHV) petrol engine $25^{\circ}$ inclined cylinder horizontal shaft engine and aim of the coating is to protect the heat to move outside, somewhere it raise the $\mathrm{TE}$ and condensed the harmful gases against the exhaust as related to the conventional engine. Practical study about TBC on diesel engine performs at various loads. This coating acts as the insulation and increases the heat of the combustion chamber. Ceramic coated engine increases $\mathrm{BTE}$ as it depends on fuel consumption. Fuel consumption decreases in modified engine so BTE is increase, decreases VE, decrease in BSFC as it depends on the BP and as the $\mathrm{BP}$ is increased BSFC is decreases, increase the exhaust gas temperature (EGT) due to complete combustion when compared with standard engine. Coated piston increases BTE and decrease SFC at all loads. The thermal fatigue can be reduced, and the combustion and pressure have high heat release due to complete combustion.

Ceramic material becomes more important since the first invention of low heat rejection engine. Ceramic material has less thermal conduction coefficient and lower in weight when compare with the conventional engine material Gataowski. In modern time many types in quality is achieved. Now new material is named as advanced technology ceramics has been produced in late $20^{\text {th }}$ century. Ceramic material consists of pure oxides such as Zirconia $\left(\mathrm{ZrO}_{2}\right)$, Alumina $\left(\mathrm{AlO}_{2}\right)$, Magnesia $(\mathrm{MgO})$, Berillya $(\mathrm{BeO})$ and other non-oxide also.

The most important material in ceramic materials is Zirconia due to its properties and application. The important property of Zirconia is its high temperature resistance when compare with other ceramic and conventional material used. When see on other properties of ceramic material than its melting point temperature and 


\section{SJIF Impact Factor 2021: 8.013| ISI I.F.Value:1.241| Journal DOI: 10.36713/epra2016 $\quad$ ISSN: 2455-7838(Online) EPRA International Journal of Research and Development (IJRD)}

Volume: 6 | Issue: 8 | August 2021

- Peer Reviewed Journal

durable under thermal shocks. Zirconia has high wear resistance and it is mostly used in diesel engine and other turbine blades to decrease heat transfer.

\section{METHODOLOGY}

\section{Coating Material}

Zirconia can be found in three crystal structures.

These are monolithic $(\mathrm{m})$, tetragonal $(\mathrm{t})$ and cubic (c) structures. Monolithic structure is stable between room temperature and $1170{ }^{\circ} \mathrm{C}$ while it turns to tetragonal structure above $1170{ }^{\circ} \mathrm{C}$. Tetragonal structure is stable up to $2379{ }^{\circ} \mathrm{C}$ and above this temperature, the structure turns to cubic structure. Usually cracks and fractures are observed during changing phases because of $8 \%$ volume difference while transitioning to tetragonal structure from monolithic structure.

\begin{tabular}{|l|l|}
\hline Density $\left(\mathrm{g} / \mathrm{cm}^{3)}\right.$ & 4 \\
\hline Compressive Strength $(\mathrm{MPa})$ & 680 \\
\hline Micro Hardness & 880 \\
\hline Boiling Point $\left({ }^{\circ} \mathrm{C}\right)$ & 2972 \\
\hline Modulus of Elasticity $(\mathrm{GPa})$ & 230 \\
\hline Toughness $\left(\mathrm{MPa} / \mathrm{m}^{1 / 2}\right)$ & 3.20 \\
\hline Poisson's Ratio & 0.27 \\
\hline Molar Mass $(\mathrm{g} / \mathrm{mol})$ & 79.87 \\
\hline Thermal Conductivity $(\mathrm{W} / \mathrm{mk})$ & 11.7 \\
\hline Melting Point $\left({ }^{\circ} \mathrm{C}\right)$ & 1870 \\
\hline
\end{tabular}

Table 1.2 Zirconia Properties

To avoid this and make zirconia stable in cubic structure at room temperature, alkaline earth elements such as $\mathrm{CaO}$ (calcium oxide), $\mathrm{MgO}$ (magnesia), $\mathrm{Y}_{2} \mathrm{O}_{3}$ (yttria) and oxides of rare elements are added to zirconia. Zirconia based ceramic materials stabilized with yttria have better properties compared with Zirconia based ceramic materials which are stabilized by magnesia and calcium oxide (Yaşar, 1997; Geçkinli, 1992). In practice, partially stabilized cubic zirconia (PSZ) which contains monolithic and tetragonal phases as sediments, is preferred

\begin{tabular}{|l|l|}
\hline \multicolumn{1}{|c|}{ Coating Process } & \multicolumn{1}{c|}{ Plasma spray Process } \\
\hline Material & Zirconia $\left(\mathrm{ZrO}_{3}\right)$ \\
\hline Material coating & $0.2 \mathrm{~mm}$ \\
\hline Binder & $\mathrm{NiCrAl}$ \\
\hline Binder coating & $0.1 \mathrm{~mm}$ \\
\hline
\end{tabular}

\section{Table 1.3 Specification of Coating Process}

Plasma spray coating is method in which heated materials are sprayed into the surface. There are two primary preferences primarily. First, it can be done at higher temperature in which melting of other known materials can be occur and second it can provide better heat transfer by others. In this method, materials which are in powder form and have some specific size can use easily. The main purpose of using plasma spray coating is to make a thin layer that has high protection values over a non-costly surface. Material places in the form of powder in this method then enters in plasma jet and it comes from plasma torch. Temperature in jet is $10,000 \mathrm{~K}$ which melts the material and run towards the substrate and at this place melted material deposited rapidly. There are two variants: owing to its improved mechanical properties and importance of martensitic transition. Partially stabilized zirconia has been commercially categorized since the early 70 s. Table contains partially stabilized zirconia types and their properties.

\section{Coating Process}

Technique used for coating is the plasma spray method. Information about the coating process is given in below table,

Spray and fuse, and spray fuse. In spray and fuse, the fusion is done after deposition using one of several techniques, such as flame or torch, induction, or vacuum, inert, or hydrogen furnaces. In spray-fuse, the deposition and fusion are done simultaneously. 


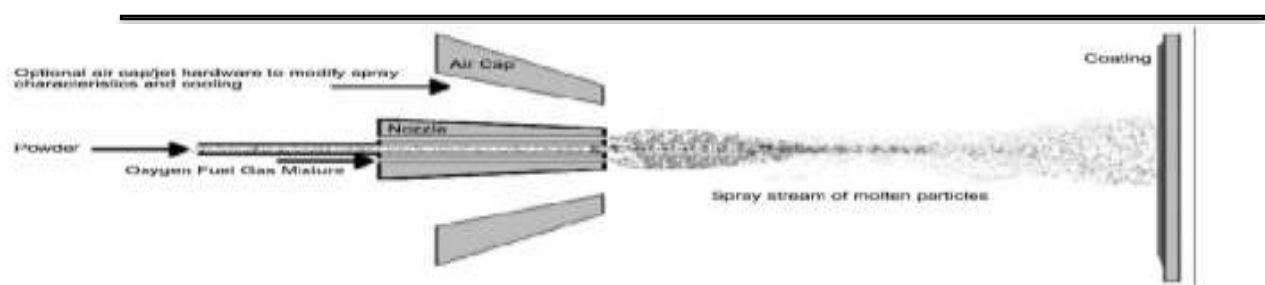

Figure 3.2 Plasma Spray Coating System

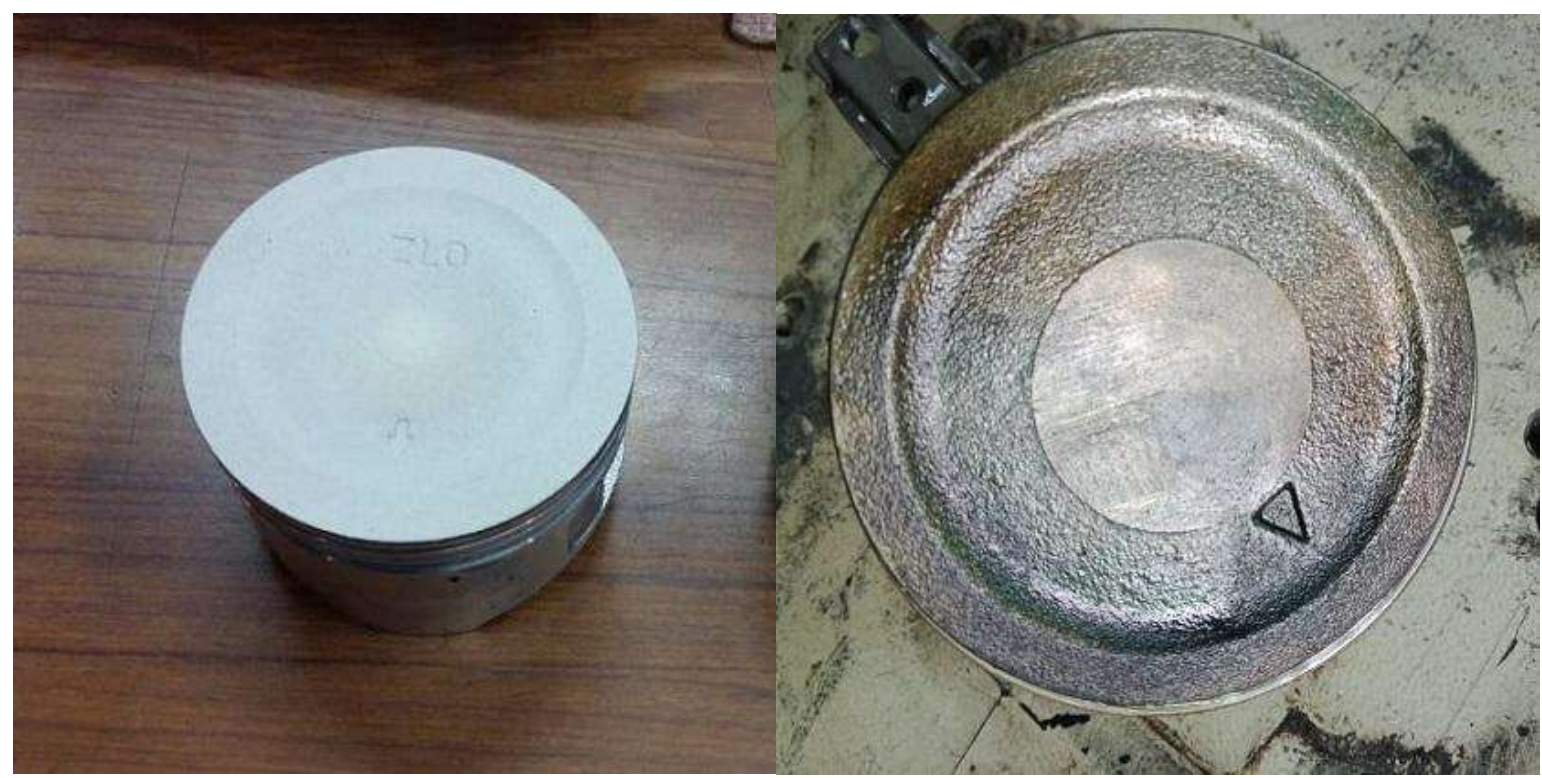

\section{Observational Step and Procedure}

Single cylinder 4-stroke spark ignition engine is used in this experiment. Four stroke cycle engine $\mathrm{s}$ is working at completed four stroke of the piston or two revaluation of the crank shaft it is called as four stroke

\begin{tabular}{|l|c|}
\hline \multicolumn{1}{|c|}{ Engine Type } & Four-stroke single cylinder OVH petrol engine \\
\hline Dry Weight & $15.1 \mathrm{~kg}$ \\
\hline Engine Oil Capacity & $0.6 \mathrm{Liter}$ \\
\hline Starter & Recoil \\
\hline Net Power & $3.6 \mathrm{~kW}(4.8 \mathrm{HP}) / 3600 \mathrm{rpm}$ \\
\hline Displacement & $163 \mathrm{~cm}^{\wedge} 3$ \\
\hline Cylinder Sleeve Type & Cast iron sleeve \\
\hline Bore x Stroke & 68 x $45 \mathrm{~mm}$ \\
\hline Ignition System & Transistorized \\
\hline Fuel Tank Capacity & $3.1 \mathrm{Liter}$ \\
\hline Dimension $($ L $\mathrm{x}$ W $\mathrm{x}$ H) & $312 \times 362 \times 346 \mathrm{~mm}$ \\
\hline Max. net torque & $10.3 \mathrm{Nm}(1.05 \mathrm{kgfm}) / 2500 \mathrm{rpm}$ \\
\hline Cont. rated Power & $2.5 \mathrm{~kW}(3.4 \mathrm{HP}) / 3000 \mathrm{rpm}$ \\
& $2.9 \mathrm{~kW}(3.9 \mathrm{HP}) / 3600 \mathrm{rpm}$ \\
\hline Compression Ratio & $9.0: 1$ \\
\hline Fuel cons. At cont. rated power & $1.4 \mathrm{~L} / \mathrm{h}-3600 \mathrm{rpm}$ \\
\hline
\end{tabular}

Table 1.4 Engine specification

engines. It has $68 \mathrm{~mm}$ bore and $45 \mathrm{~mm}$ stroke length. Power of the engine at study time is $3.5 \mathrm{~kW}(4.8 \mathrm{HP})$ and there is $3600 \mathrm{rpm}$. Engine showed in below figure. 


\section{SJIF Impact Factor 2021: 8.013| ISI I.F.Value:1.241| Journal DOI: 10.36713/epra2016 ISSN: 2455-7838(Online) EPRA International Journal of Research and Development (IJRD) Volume: 6 | Issue: 8 | August 2021 \\ - Peer Reviewed Journal}

With coated and non-coated piston, engine rpm set at 3600. Engine performance calculated with coated and noncoated engine at different speed and constant load. The experiments were conducted at four different speeds as 2000, 2500, 3000 and $3500 \mathrm{rpm}$. Other parameters calculated such as brake specific fuel consumption, brake thermal and indicated thermal efficiencies, mechanical efficiency, brake specific energy consumption, air fuel ratio and exhaust gas temperature obtained. The variations of these parameters except exhaust gas temperature plotted with respect to Engine Speed and variation of exhaust gas temperature plotted with respect to Break Power.

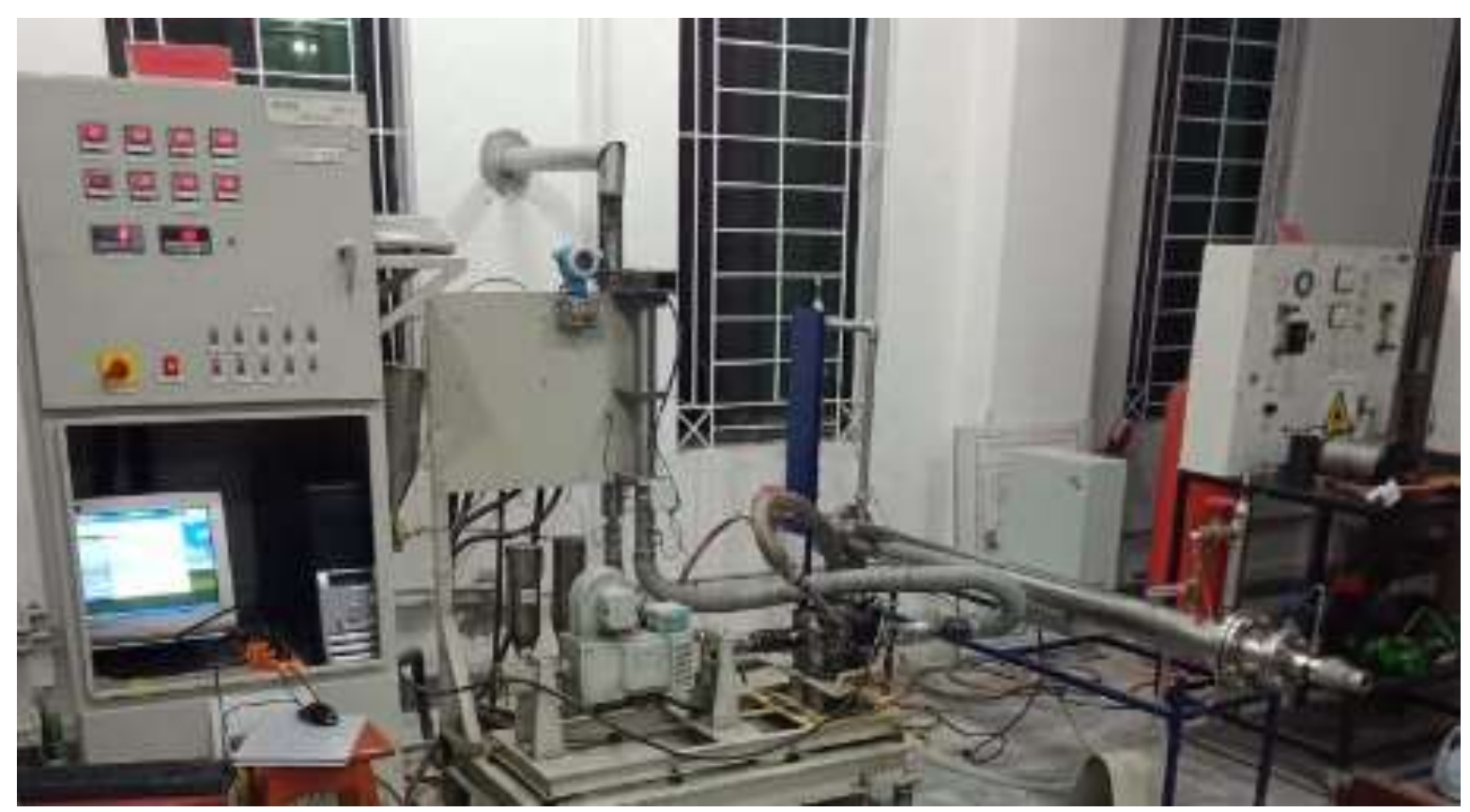

Figure 3.5 Engine Test Bed Model. THO3

\section{RESULTS AND DISCUSSION \\ Brake Specific Fuel Consumption}

The Brake specific fuel consumption (BSFC) is amount of fluid (fuel) needed to get one watt of power. It is measure from the amount of fuel consume to the power generated at output shaft. BSFC for conventional and modified engine show in figure. Results presents that the BSFC of both conventional and modified engine decreases by increasing brake power. Fuel consumption (FC) of the modified engine is less due to the TBC of the YttriaStabilized Zirconia. Thus, for coated engine BSFC is also smaller than the conventional engine.

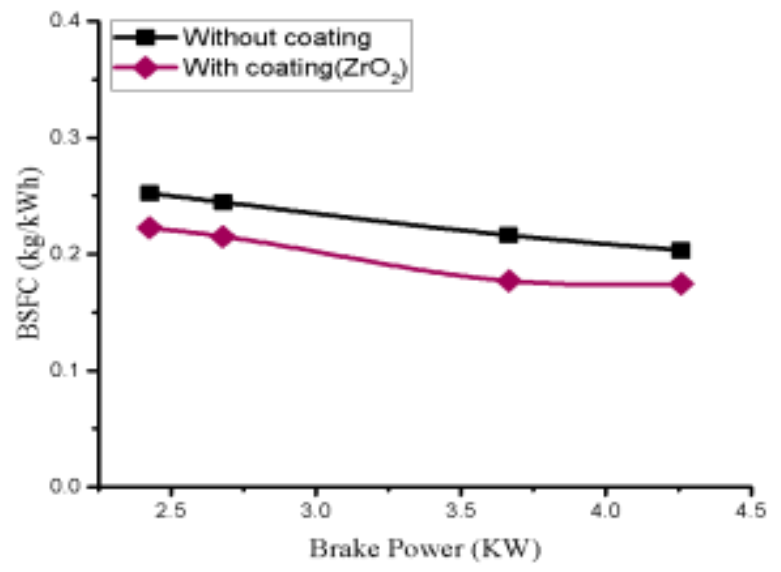

Figure 4.1 Comparison of Brake power with BSFC Brake thermal efficiency: 


\section{EPRA International Journal of Research and Development (IJRD) \\ Volume: 6 | Issue: 8 | August 2021 \\ - Peer Reviewed Journal}

BTE of modified engine increases to $7.5 \%$ at 3000 rpm engine speed as compared to the typical engine due to the TBC of the Yttria Stabilized Zirconia on piston crown. This is because the zirconia coating of the piston head reduces heat losses of coolant and higher heat is available in the chamber, which aids proper combustion and reduces fuel burn.

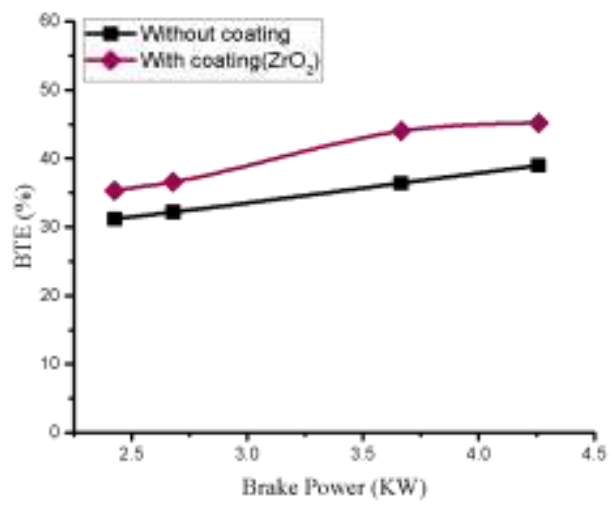

\section{Indicated Thermal Efficiency}

The ITE of the coated piston increases to $9.6 \%$ at $3000 \mathrm{rpm}$ engine speed as compared to the typical engine. This is because the coated engine reduces heat loss and
Figure 4.2 Comparison of Brake power with BTE

provides better combustion efficiency correlated to the uncoated engine. In addition, fuel consumption in coated piston decreases due to better combustion.

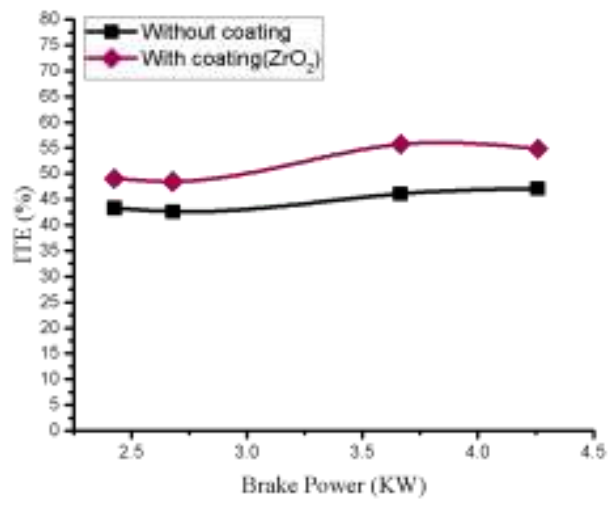

Figure 4.3 Comparison of Brake power with ITE

Mechanical Efficiency

Mechanical efficiency rises by increasing the brake power of engine. ME of modified engine increases in comparison to the conventional engine between 4 and $10 \%$ at different engine speed. 


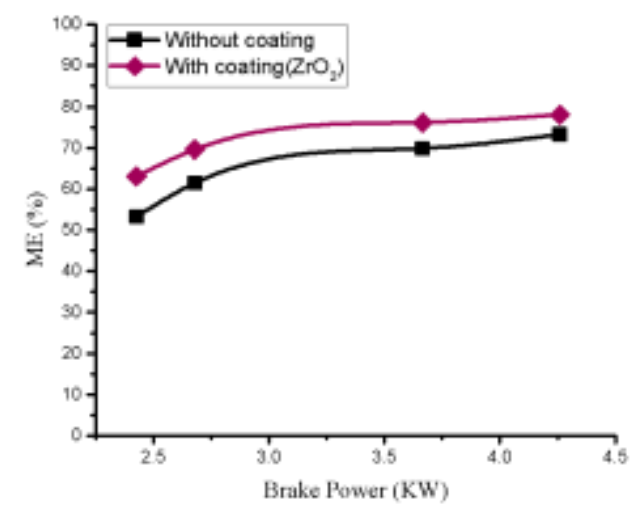

\section{Volumetric Efficiency}

The variety in VE of conventional and coated engine is show in figure. It decreases with increasing

\section{ene power with Me} engine power, but the decrease in the coated engine is greater.VE of the modified engine decreases between 3 and $9 \%$ compared to the conventional engine.

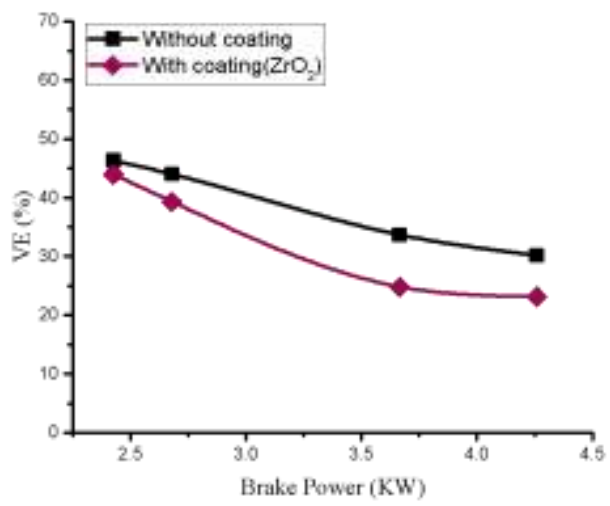

\section{Exhaust Gas Temperature}

The exhaust gas temperature (EGT) of modified engine is $1-3{ }^{\circ} \mathrm{C}$ higher because more heat in chamber
Brake power with VE

increases the temperature of the exhaust gas. Turbocharger can be used to return this heat to the engine and improve engine efficiency.

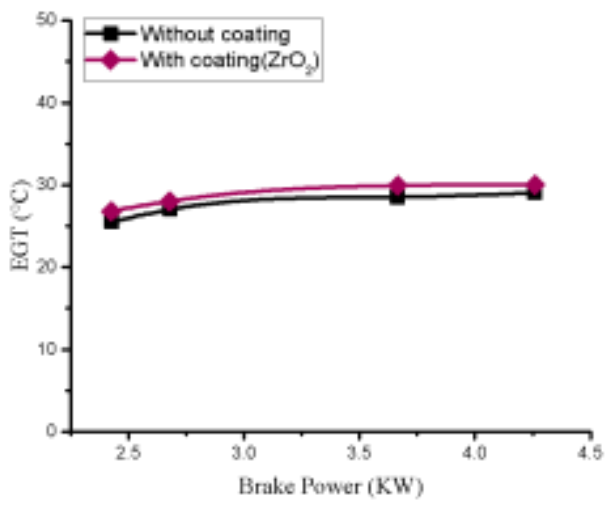

Figure 4.6 Comparison of Brake power with EGT 


\section{SJIF Impact Factor 2021: 8.013| ISI I.F.Value:1.241| Journal DOI: 10.36713/epra2016 ISSN: 2455-7838(Online) EPRA International Journal of Research and Development (IJRD)}

Volume: 6 | Issue: 8 | August 2021

\section{CONCLUSION}

We Conclude that Performance analysis of the modified engine is better as compared to without coated engine.

BSFC of coated engine is $2-4 \%$ lower as compared to uncoated engine.

Thermal efficiency of modified engine increases by $4-8 \%$ compared to without coated engine.

The indicated thermal efficiency of modified engine has an increase of 5 to $10 \%$ compared to with coated.

The mechanical efficiency of modified engine increases 4$10 \%$ compared to without coated.

The volumetric efficiency of modified engine reduced by $3-9 \%$ compared to the without coated.

The exhaust gas temperature of the modified engine increases by $1-3{ }^{\circ} \mathrm{C}$ compared to uncoated engine and by the turbocharger we can use heat energy of exhaust again.

The heat energy released from the fuel in TBC engine is higher as compared to that of without coated engine with less emissions.

\section{REFERENCES}

1. Jaichandar, S. and Tamilporai, P., The Status of Experimental Investigations on Low Heat Rejection Engines, SAE Technical Paper, No. 2004-01-1453, 2004

2. Assanis, D.N., et al., The Effects of Ceramic Coatings on Diesel Engine Performance and Exhaust Emissions, SAE Technical Paper, No. 910460, 1991

3. Rupangudi, S.K., et al., Study of Effect of Coating of Piston on the Performance of a Diesel Engine. SAE International Journal of Materials and Manufacturing, 7(3), pp.633-637, 2014

4. Afify, E.M. and Klett, D.E., The Effect of Selective Insulation on the Performance, Combustion, and NO Emissions of a DI Diesel Engine, SAE Technical Paper, No. 960505,1996

5. Ramu, P. and Saravanan, C.G., Effect of ZrO2-Al2O3 and SiC Coating on Diesel Engine to Study the Combustion and Emission Characteristics, SAE Technical Paper, No. 2009-01-1435, 2009

6. Assanis, D.N. and Mathur, T., The Effect of Thin Ceramic Coatings on Spark-Ignition Engine Performance. SAE transactions, pp.981-990, 1990

7. Gosai, D.C. and Nagarsheth, H.J., Performance and Exhaust Emission Studies of an Adiabatic Engine with Optimum Cooling. Procedia Technology, pp.413-421, 2014

8. Rupangudi, S.K., et al., Study of Effect of Coating of Piston on the Performance of a Diesel Engine. SAE International Journal of Materials and Manufacturing, 7(3), pp.633-637, 2014

9. Muthusamy, J., et al., Experimental Investigation of Thermal Barrier (8YSZ-TiO 2-Al $2 \mathrm{O}$ 3) Coated Piston Used in Direct Injection Compression Ignition Engine, Thermal Science, 20, 2016

10. Modi, R.S. and Modi, M.A., IC Engine Performance Using Ceramic Coated Piston, Journal of Mechanical and Civil Engineering (IOSR-JMCE), Volume 14, Issue 2 Ver. IV, 2017 